\title{
INFLUENCING FACTORS OF BRAND PERCEPTION ON CONSUMERS' REPURCHASE INTENTION: AN EXAMINATION OF ONLINE APPAREL SHOPPING
}

\author{
Wajeeha Aslam* \\ Marija Ham** \\ Kashif Farhat***
}

Received: 18. 2. 2017

Preliminary communication

Accepted: 4. 12. 2018

UDC 658.6:004.78

DOI https://doi.org/10.30924/mjcmi/2018.23.2.87

\begin{abstract}
The objective of this study is to analyse the impact of brand perception on repurchase intention in the case of online apparel shopping in Pakistan. This study is based on a more holistic approach than previous studies, incorporating multiple theories and concepts of brand perception in order to capture the complexity of influences and to explain repurchase intention as a dependent variable. The theoretical framework of the study was developed on the basis of schema theory, image-congruence theory, commitment-trust theory and on the basis of earlier empirical findings. The study investigates brand experience, brand image-congruence, brand affect, and brand trust as influencing variables
\end{abstract}

\section{INTRODUCTION}

The world of e-commerce has recently progressed at an astonishing speed. According to Statista (2018), the worldwide online retail sales will grow to $\$ 4135$ billion (U.S. dollar) in 2020. Even though Pakistan is the late entrant in the realm of e-commerce, it has recorded an on repurchase intention. In total, 396 responses were gathered from online consumers of Karachi, Pakistan, using a non-probability convenience sampling. Exploratory factor analysis (EFA) and Structural Equation Modeling (SEM) were employed as data analysis techniques using SPSS 22 and AMOS 22 respectively. The results of the study showed significant positive influences of all the proposed constructs on repurchase intention except for the brand experience.

Keywords: Repurchase intention, brand experience, brand trust, brand affect, brand image, online apparel shopping, Pakistan.

immense rise in the online shopping trend (PakistanToday, 2018).

According to Duryee (2012) and Enright (2013), after computers and electronics, apparel and footwear products are the fastest growing segment in e-commerce. Having a great experience in online shopping, consumers become more price- and

\footnotetext{
* Wajeeha Aslam, Lecturer, Department of Management Sciences, IQRA University, Abid Town, Block 2, Gulshan e Iqbal, 75300 - Karachi, Pakistan, Phone: +992 313 2519224; Fax: ++92 21 34987806, e-mail: wajeeha_aslam_87@live.com

** Marija Ham (Corresponding author), Associate professor, Faculty of Economics in Osijek, Gajev trg 7, 31000 Osijek, Croatia, Phone: ++385 31 224400; Fax: ++385 31 211604, e-mail: mham@efos.hr

*** Kashif Farhat, Lecturer, Department of Marketing, Muhammad Ali Jinnah University, Shahra-e-Faisal, 75300 Karachi, Pakistan, Phone: ++92 312 2702084; Fax: ++92 21 34311327, e-mail: kashif.farhat@gmail.com
} 
product-savvy which has intensified the competition between the retailers (Jordan, 2013). With growing desires and needs, consumers are demanding higher quality products, more varieties, better service scopes, and more mindful and responsive customer service. To achieve competitive advantage and develop customer retention, companies started to promote recognized brands because branded and known products sell better online (Jordan, 2013; Chen$\mathrm{Yu}$ et al., 2016). According to Park and Lennon (2009), a strong brand name has a positive impact on an online store image and perceived value, which leads to purchase intention in online apparel shopping.

With a continuous progression in online shopping, many consumers have purchased a brand online and have also made repeat purchases (Chen-Yu et al., 2016). Acquiring new customers may cost up to 6 or 7 times more than retaining existing customers (Shaw, 2013) and according to Williams (2014), repeated customers may spend $67 \%$ more than new customers and tend to become more loyal. This highlights the fact that retaining a customer is more beneficial for companies. The importance of repeat purchase is vastly documented in trade literature (Jao, 2014), but studies examining repeat purchases in online apparel shopping are very limited. In the past, a few researchers have examined the consumers' intention for website purchases (Jones \& Kim, 2010; Park \& Lennon, 2009), but very few studies have focused on repurchase intention in the context of apparel industry. According to Kim and $\mathrm{Na}$ (2015), to be competitive, online shopping industry needs to know what customers pay attention to and what makes them repurchase.

To fill this gap, the objective of this study is to analyse influencing factors of brand perception on online repurchase intention in apparel shopping. This study includes multiple dimensions of brand perception which includes brand experience, brand image-congruence, brand affect, and brand trust.

The paper is structured as follows; the following section of the paper is related to the theoretical framework and hypotheses development. Later, methodology is discussed and finally, the results of the study and the conclusion are presented.

\section{THEORETICAL FRAMEWORK AND HYPOTHESES DEVELOPMENT}

\subsection{Theoretical framework}

Understanding the pattern of interaction or the ways in which the dimensions of brand association function as antecedents, is vital to encourage the preferred consumer response to a brand (Chen-Yu et al., 2016). Brand association refers to how information is linked with the brand in the mind of a consumer. Brand synthesis approach suggested by Keller (2003) determines numerous dimensions of brand associations which influence consumers' behaviour. By using Keller's (2003) holistic approach, brand perception is considered to be a multi-dimensional construct. These dimensions are: experimental, symbolic, emotional/affective, and cognitive. Christodoulides et al. (2006) highlight three types of brand perception which play a significant role while purchasing apparel online. These are: brand experience, brand affect, and brand trust. Brand experience is an experimental dimension of brand perception which explains the perception of a consumer after the purchase and experience with the specific brand (Chen-Yu et al., 2016). Brand affect is the 
affective feeling of the consumer towards a specific brand and this is the emotional dimension of brand perception. Brand trust is the cognitive dimension of the brand perception which refers to the consumer's feeling of safety while purchasing a product online (Chen-Yu et al., 2016).

According to Sirgy (1985), an additional type of brand perception is brand imagecongruence (symbolic dimension) based on image-congruence theory which explains consumer's perception of the consistency between a particular brand image and his/ her own self-image. According to Rhee and Johnson (2012), in apparel items symbolic aspect is essential as it expresses self- image.

The theoretical framework of this study was developed on the basis of schema theory, image-congruence theory, commitmenttrust theory and on the basis of earlier empirical findings.

\subsection{Antecedents of brand affect}

According to Peter \& Olson (2010), affect refers to consumer's emotions about an object or event, or in the case of brand affect, whether they like or dislike the brand. Consumer's feelings or emotions about the brand influence the consumer-brand relationship (Loureiro et al., 2012). Consumer that experiences the feeling of love creates a strong bond with the brand (Chen-Yu et al., 2016). According to Batra et al. (2012), love towards a brand plays a vital role in the long-term relationship. In this study, brand experience and brand-image congruence are proposed as antecedents of brand affect.

\subsubsection{Brand experience and brand affect}

Consumers' cognitive and affective responses develop on the basis of their experience (Peter \& Olson, 2010). Consumers who repeatedly buy a specific product know the brand not only because of the advertisement, but also from the experience they gain with the brand. Schema theory explains brand experience which describes how people perceive new experiences by triggering the mental schema stored in their memory (Bartless, 1932). Furthermore, it is the formation of an impression in the mind of a consumer resulting from the offer of a brand. Brand experience acts as a memory scheme and influences the consumer in future purchases (Alba \& Hasher, 1983).

According to Kim (2012), by managing customer's experience, marketers can build strong brands. Iglesias et al. (2011) argued that stronger brand experience may cause positive response from the consumer and Kim and Ock (2008) provided evidence that online brand experience renders positive or negative brand affect. According to this, it can be hypothesized that:

$H_{1}$ : Brand experience has a significant and positive impact on brand affect.

\subsubsection{Brand image-congruence and brand affect}

According to Spector (1961), an organization can be perceived as a human and create a certain image in the mind of a consumer. Hence, consumers can form associations with brands similarly to the associations and relationships with each other in a social context (Chen-Yu et al., 2016). Sirgy (1985) proposed an image-congruence theory which explains that consumers match the product or a brand image with their self-image. A consumer that perceives a high level of congruence between his/her self-image feels more positive about the brand (Moon, 2007; Rhee \& Johnson, 2012). According to the above, it can be stated that:

$H_{2}:$ Brand image-congruence has a significant and positive impact on brand affect. 


\subsection{Antecedents of brand trust}

Consumers' trust has been acknowledged in marketing literature as a crucial factor for successful business trades and in the development and management for a long-term customer relationship (Hongyoun Hahn \& Kim, 2009). In the e-commerce industry, trust is considered a particularly important factor as online purchases bring more risk (Smith \& Brynjolfsson, 2001). According to Bhatnagar et al., (2000), a consumer feels a greater risk in online apparel purchasing than in other products categories, as in online apparel purchasing there is high uncertainty about fabric, colour and size. In the process of online apparel purchasing, the perceived risk is high, therefore trust plays a significant role (Chen-Yu et al., 2016). In this study, brand experience, brand image-congruence and brand affect are the proposed antecedents of brand trust.

\subsubsection{Brand experience and brand trust}

Positive experience with the brand and the knowledge about the brand provide a sense of trust in the mind of a consumer (Lau \& Lee, 1999). According to Sharifi and Esfidani (2014), previous experience acts as a source of trust. Similarly, Weisberg et al., (2011) stated that positive experience of the consumer with the brand has a significant relationship with brand trust. According to this, it can be hypothesized that:

$H_{3}$ : Brand experience has a positive and significant impact on brand trust in online apparel shopping.

\subsubsection{Brand image-congruence and brand trust}

According to Meijinders et al. (2009), perceived similarity plays an essential role in building the feeling of trust. Similarly, Coulter and Coulter (2002) stated that congruence between brand image and self-image establishes trust. However, only a limited number of studies have examined this relationship. Han and Hyun (2013) proved that image-congruence in a luxury restaurant has a positive impact on customer's trust. The same results were found by Rocereto (2007) in a case of apparel brand. According to this, it can be hypothesized that:

$H_{4}$ : Brand image-congruence has a positive and significant impact on brand trust in online apparel shopping.

\subsubsection{Brand affect and brand trust}

Positive feelings towards a brand motivate the consumer to learn and acquire more knowledge about the brand, which develops consumer's trust in the brand (Lau \& Lee, 1999). A consumer's love for a brand positively diffuses uncertainty and builds confidence (Batra et al., 2012). Empirical evidence that brand affect increases the level of trust towards the brand in online shopping was found by Lin and Lee (2012). According to this, it can be hypothesized that:

$H_{5}:$ Brand affect has a positive and significant impact on brand trust in online apparel shopping.

\subsection{Antecedents of brand repurchase intention}

Brand repurchase intention refers to consumer's favourable action while making future purchases. According to Morwitz et al. (2007), purchase intention is a measure that predicts the actual purchases. Consumer's brand repurchase intention is derived from brand experience, brand image-congruence and brand trust (Chen-Yu et al., 2016).

\subsubsection{Brand experience and brand repurchase intention}

Study conducted by Temkin et al (2009) confirmed that brand experience has a significant impact on willingness to 
repurchase. In addition, according to Walter et al. (2013), brand experience enhances customer loyalty. In the case of online apparel shopping, Shim (2012) proved that brand loyalty is predicted by brand experience. According to this, it can be hypothesized that:

$H_{6}:$ Brand experience has a positive and significant impact on brand repurchase intention in online apparel shopping.

\subsubsection{Brand image-congruence and brand repurchase intention}

A positive relationship was found between brand image-congruence and purchase intention (Das, 2015). However, very few studies have examined the relationship between brand image-congruence and repurchase intention. Chen-Yu et al. (2016) examined the relationship beween these two variables in online apparel shopping and found a positive and significant impact of brand image-congruence on brand repurchase intention. According to Kressmann et al. (2006), brand image-congruence has a significant impact on brand loyalty. Consumers that have a high degree of consistency between brand-image and selfimage have high chances of buying the product on a continuous basis or to repeat purchases. According to this, it can be hypothesized that:

$H_{7}$ : Brand image-congruence has a positive and significant impact on brand repurchase intention in online apparel shopping.

\subsubsection{Brand trust and brand repurchase intention}

According to the commitment-trust theory, a consumer gets committed when the sense of uncertainty decreases in his/ her mind (Morgan \& Hunt, 1994). Applying this theory in the context of shopping, it can be stated that consumers buy trusted brands to avoid disappointments (Chen-Yu et al., 2016). If a consumer starts trusting the brand, he/she becomes loyal (Jang, 2007; Lee et al., 2011; Loureiro et al., 2012). Lin and Lee (2012) also stated that a consumer repeats purchases if he/she trusts a brand. According to the above, it can be hypothesized that:

$H_{8}$ : Brand trust has a positive and significant impact on brand repurchase intention in online apparel shopping.

The hypothesized conceptual model is presented in Figure 1.

Figure 1: The research model

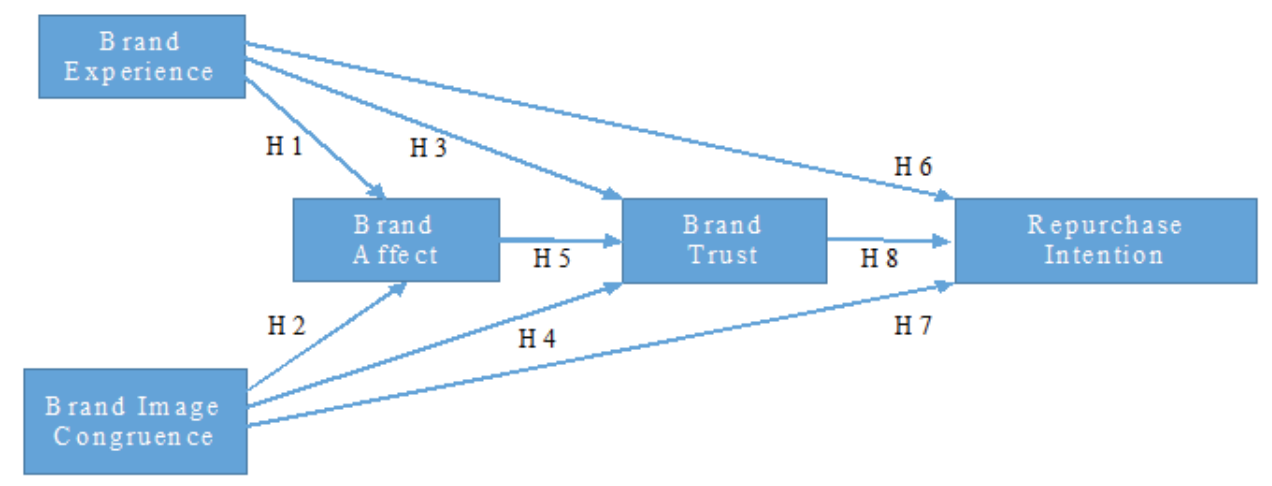

Source: Authors'work 


\section{RESEARCH METHOD}

\subsection{Instrument development}

A survey questionnaire was used to measure five constructs: brand experience, brand image-congruence, brand affect, brand trust, and brand repurchase intention. The questionnaire comprised of two parts; the first part refers to the respondents' demographic profile and the second part refers to the constructs. Questionnaire constructs were designed based on previous researches mentioned in Table 1. The items for measuring brand experience, brand affect and brand repurchase intention were adapted from Chen-Yu et al. (2016). The items measuring the variable brand image-congurence were adapted from Han (2006) and Chen-Yu et al. (2016), and the items for measuring the brand trust variable were adapted from Park and Stoel (2005) and Chen-Yu et al. (2016). All of the items were based on a 5-point Likert scale with the range from stronlgy agree (5), agree (4), neutral (3), disagree (2) to strongly disagree (1). The first part of the questionnaire includes questions related to the age, gender, education level, and online shopping frequency. The questionanire was pilot tested $(n=60)$ to ensure the validity.

\subsection{Sample and data collection}

Based on convenience sampling, data was gathered in December 2016 from respondents in Karachi, Pakistan. The respondents were consumers above 20 years of age or older who had had an experience of online shopping. The responses were collected through an online Google form and by distributing hard copies of the questionnaire to respondents. The respondents were approached by going to different places in Karachi such as shopping malls, restaurants, and universities. Before giving the questionnaire to be filled out, they were verbally asked about their online shopping experience to assure right respondents. The person who had not shopped online was not considered a respondent and, therefore, the questionnaire was not given to them to fill out.

Before proceeding to data analysis, it was of utmost importance to check the reliability of the data collection instrument. Therefore, the initial 60 responses were collected and analysed for internal consistency of the instrument using Cronbach's Alpha reliability analysis. Demo et al. (2012) suggested that alpha coefficient greater than 0.70 should be taken as acceptable for exploratory purposes. The calculated values of all the construct scales in this study met the cut-off value of 0.70 . Hence, the reliability of the instrument to be further used to gather the data was confirmed.

In total, 437 responses were gathered and data-screening procedures were applied. For the purpose of detecting and deleting the univariate and multivariate outliers, Z-Score was computed using standardized values for detecting univariate outliers and Mahalanobis Distance $\left(\mathrm{D}^{2}\right)$ for detecting multivariate outliers. Univariate outliers were considered at Z-Score $\leq 3.00$ and $\geq-3.00$, according to the criteria suggested by Aggarwal (2013), whereas Mahalanobis Distance for each construct along with their p-value was calculated. According to the criteria suggested by Kline (2011), p-value $\leq$ 0.001 were considered as multivariate outliers. Under these parameters, the total sample data of 437 responses was examined and 34 univariate outliers and 7 multivariate outliers were found. Hence, the total sample of 396 responses was left after the deletion of univariate and multivariate outliers. 


\section{DATA ANALYSIS AND RESULTS}

\subsection{Sample characteristics}

Overall, 396 responses were used for further analysis with SPSS 22.0 and AMOS 22.0. Slightly more males $(53.3 \%)$ than females $(46.7 \%)$ responded. The majority of respondents lie in the age bracket of 20-25 and $26-31$ which amounts to $41.4 \%$ and $40.4 \%$ respectively. According to the education profile, $40.4 \%$ of the respondents are under graduates and $38.9 \%$ are graduates. Additionally, all the participants bought online at least one apparel product in the past 6 months, which makes them online apparel shoppers. For most of the participants $(68.2 \%)$, the frequency of purchasing apparel products was twice in six months.

\subsection{Measurement reliability and validity tests}

With the purpose of extracting statistically possible factors in accordance with the correlation, principal component analysis was performed with varimax rotation using
SPSS 22.0. The KMO measure of sampling adequacy was found to be 0.833 which exceeds the 0.80 threshold level proposed by Demo et al. (2012). Factor loadings above 0.70 have been considered as excellent, whereas, those between the range of 0.60 and 0.70 have been considered as good (Demo et al., 2012).

For model fitness, confirmatory factor analysis was performed using Amos 22.0. Based on the results of various indices, the model showed good fitness. The value of Chi-Square is $(\mathrm{CMIN} / \mathrm{DF}=2.08)$ which is in the acceptable range of $3: 1$ (Bagozzi \& $\mathrm{Yi}, 1988)$. RMSEA value is 0.052 , which also lies in the acceptable range $(<0.07)$ determined by Byrne (2013). The values of incremental fit measures (GFI $=0.924$, $\mathrm{NFI}=0.909, \mathrm{IFI}=0.951, \mathrm{TLI}=0.936, \mathrm{CFI}=$ 0.950 ) also confirmed that the model is adequate for further analysis (Hair et al., 2010; Bagozzi \& Yi, 1988). Parsimony fit measures $(\mathrm{PCFI}=0.740$ and $\mathrm{PNFI}=0.709)$ also lie in the threshold value suggested by Bagozzi and Yi (1988).

Table 1: Scale items and results of exploratory and confirmatory factor analysis and convergent validity examinations

\begin{tabular}{|c|c|c|}
\hline Items & $\begin{array}{l}\text { EFA Item } \\
\text { Loadings }\end{array}$ & $\begin{array}{l}\text { CFA Item } \\
\text { Loadings }\end{array}$ \\
\hline \multicolumn{3}{|l|}{ Brand Experience (BE) Cronbach's $\alpha=0.899, C R=0.90$ and $A V E=0.70$} \\
\hline \multicolumn{3}{|l|}{ Adapted from : Chen-Yu et al. (2016); Bruner (2012); Yoon \& Youn (2016) } \\
\hline $\begin{array}{l}\text { Purchasing and wearing apparel products of the selected brand have been a good } \\
\text { experience. }\end{array}$ & 0.85 & 0.83 \\
\hline $\begin{array}{l}\text { I am satisfied with my experience of buying and wearing apparel products of the } \\
\text { selected brand. }\end{array}$ & 0.91 & 0.94 \\
\hline This brand arouses feelings and sentiments. & 0.89 & 0.87 \\
\hline I found this brand interesting in a sensory way. & 0.79 & 0.69 \\
\hline \multicolumn{3}{|l|}{ Brand Image-Congruence (BIC) Cronbach's $\alpha=0.87, C R=0.86$ and $A V E=0.56$} \\
\hline \multicolumn{3}{|l|}{ Adapted from: Chen-Yu et al. (2016); Han (2006) } \\
\hline Wearing the selected brand reflects who I am. & 0.78 & 0.67 \\
\hline $\begin{array}{l}\text { The overall image of the people who wear the selected brand is consistent with my own } \\
\text { image. }\end{array}$ & 0.75 & 0.70 \\
\hline The image of the selected brand is consistent with how I would like to be. & 0.81 & 0.86 \\
\hline
\end{tabular}




\begin{tabular}{|c|c|c|}
\hline Items & $\begin{array}{l}\text { EFA Item } \\
\text { Loadings }\end{array}$ & $\begin{array}{l}\text { CFA Item } \\
\text { Loadings }\end{array}$ \\
\hline Wearing the selected brand reflects who I would like to be. & 0.77 & 0.75 \\
\hline The image of the selected brand is consistent with how I see myself. & 0.80 & 0.76 \\
\hline \multicolumn{3}{|l|}{ Brand Affect $(B A)$ Cronbach's $\alpha=0.825, C R=0.85$ and $A V E=0.53$} \\
\hline \multicolumn{3}{|l|}{ Adapted from: Chen-Yu et al. (2016); Bruner (2012); Chaudhuri \& Holbrook(2001) } \\
\hline My general attitude toward the selected brand is favourable. & 0.82 & 0.76 \\
\hline The selected brand is desirable. & 0.81 & 0.83 \\
\hline The selected brand is likable. & 0.63 & 0.72 \\
\hline I feel good when I use this brand. & 0.73 & 0.64 \\
\hline This brand makes me happy. & 0.79 & 0.68 \\
\hline \multicolumn{3}{|l|}{ Brand Trust (BT) Cronbach's $\alpha=0.806,, C R=0.81$ and $A V E=0.52$} \\
\hline \multicolumn{3}{|l|}{ Adapted from: Chen-Yu et al. (2016); Park and Stoel (2005) } \\
\hline $\begin{array}{l}\text { I can be assured that the apparel product of the selected brand that I purchase online will } \\
\text { look good on me. }\end{array}$ & 0.83 & 0.81 \\
\hline $\begin{array}{l}\text { I can be certain that I will save money and time when purchasing online apparel } \\
\text { products of the selected brand. }\end{array}$ & 0.75 & 0.61 \\
\hline $\begin{array}{l}\text { I can be certain that no alteration will be needed for the apparel product of the selected } \\
\text { brand that I purchase online. }\end{array}$ & 0.79 & 0.75 \\
\hline $\begin{array}{l}\text { I am confident that it will be easy to return or exchange the apparel product of the } \\
\text { selected brand purchased online. }\end{array}$ & 0.79 & 0.71 \\
\hline \multicolumn{3}{|l|}{ Brand Repurchase Intention (RPI) Cronbach's $\alpha=0.749, C R=0.88$ and $A V E=0.64$} \\
\hline \multicolumn{3}{|l|}{ Adapted from: Chen-Yu et al. (2016); Maxham III \& Netemeyer (2003); Tax et al., (1998) } \\
\hline I will purchase apparel products of the selected brand online. & 0.74 & 0.79 \\
\hline I will purchase the selected brand online the next time when I need an apparel product. & 0.79 & 0.62 \\
\hline I will recommend this brand to friends. & 0.70 & 0.79 \\
\hline I will spread a positive word-of-mouth of this brand. & 0.74 & 0.97 \\
\hline
\end{tabular}

Source: Authors'work

Convergent validity was examined via three indices. Factor loadings should be greater than 0.50 , average variance extracted (AVE) of the constructs should be greater than 0.50 and composite reliability of the constructs should be greater than 0.70 . Hair et al. (2006) recommended all of these thresholds. Discriminant validity was verified by the results showing that the AVE for each construct was larger than the square of correlation estimates associated with that construct (Hair et al., 2006). Table 1 represents the convergent validity results. All the results confirmed the proposed model with sufficient reliability and validity. Table 1 represents the value of EFA loadings, CFA loadings, Cronbach's $\alpha$, composite reliability and AVE.

\subsection{Structural equation model: Hypotheses testing}

Table 2 represents the relationships between the constructs. Seven of the eight hypotheses were statistically supported. According to the results, brand experience (BE) and brand image- congruence (BIC) have a significant impact on brand affect (BA) and explain $64.2 \%$ of brand affect variance. Based on that, it can be stated 
Table 2: Hypotheses Testing

\begin{tabular}{cccccccc}
\hline Path & & & Estimates & S.E. & C.R. & P & Hypotheses \\
\hline BA & $<---$ & BE & 0.039 & 0.022 & 1.794 & $0.043^{* *}$ & H1 - supported \\
\hline BA & $<---$ & BIC & 0.219 & 0.049 & 4.495 & $0 * * *$ & H2 - supported \\
\hline BT & $<---$ & BE & 0.087 & 0.036 & 2.429 & $0.015^{* *}$ & H3 - supported \\
\hline BT & $<---$ & BIC & 0.133 & 0.055 & 2.394 & $0.017^{* *}$ & H4 - supported \\
\hline BT & $<---$ & BA & 0.171 & 0.095 & 1.795 & $0.047 * *$ & H5 - supported \\
\hline RPI & $<---$ & BE & 0.025 & 0.024 & 1.024 & 0.306 & H6 - not supported \\
\hline RPI & $<---$ & BIC & 0.153 & 0.040 & 3.844 & $07^{* *}$ & H7 - supported \\
\hline RPI & $<---$ & BT & 0.062 & 0.029 & 2.136 & $0.033^{* *}$ & H8 - supported \\
\hline
\end{tabular}

$* * *$ Significant at $<0.01, * *$ Significant at $<0.05$

Source: Authors'work

that $\mathrm{H} 1$ and $\mathrm{H} 2$ are supported. Brand experience, brand image-congruence and brand affect also have a significant impact on brand trust (BT) and explain 52.4\% of brand trust, thus confirming the hypotheses H3, H4 and H5. Repurchase intention (RPI) was significantly impacted by brand imagecongruence and brand trust. Therefore, $\mathrm{H} 7$ and $\mathrm{H} 8$ are also supported. Only brand experience has an insignificant impact on repurchase intention in online apparel shopping which leads to the conclusion that H6 is not supported. Brand experience, brand image-congruence and brand trust explain $43.2 \%$ of repurchase intention.

\section{CONCLUSION}

Even though online purchases are growing in number, it is still crucial for companies to retain their consumers through repeat purchases (Jao, 2014). Nonetheless, this area of research has received limited academic research attention (Chen-Yu et al., 2016). In addition, a study that focused on repurchase intention in apparel industry was conducted in the USA, hence there is a gap to identify repurchase intention from the perspective of a developing country such as Pakistan. Therefore, this study investigated the interrelationships of the dimensions of brand perception: brand experience, brand image-congruence, brand affect and brand trust and their influence on the repurchase intention of a branded apparel. For this purpose, quantitative research approach was used and data was gathered from consumers who had had an experience of an online shopping of branded apparel. Initially 437 responses were gathered but in the data screening stage, it was reduced to 396 as outliers were deleted. To examine the relationships between the constructs, SEM was applied via Amos 22.

The results of the study show that brand experience and brand image-congruence have a positive association with brand affect. Brand image-congruence has a stronger impact on brand affect as it has a larger beta coefficient $(\beta=0.219)$. These results indicate that brand image- congruence and brand experience both develop a positive feeling between brand and consumer and create an emotional connection.

A positive and significant relationship was found between brand image-congruence, brand experience and brand affect with brand trust. Brand affect greatly influences brand trust $(\beta=0.171)$ followed by brand image-congruence $(\beta=0.133)$ and brand experience $(\beta=0.087)$. The result 
confirms that favourable brand experience builds trust and that when a brand portrays a congruent self-image it also fulfils the consumer psychological and social desire which also forms brand trust. Brand affect largely influences brand trust and confirms that favourable feeling and consumer's love of a brand certainly develops confidence in the brand. Positive and significant results of brand affect and brand image-congruence on brand trust were also found by Chen-Yu et al. (2016), whereas they found an insignificant impact of brand experience on brand trust in online apparel shopping. However, Walter et al. (2013) and Weisberg et al. (2011) confirmed the direct impact of brand experience on brand trust.

The results also reveal that brand image-congruence and brand trust have a significant impact on brand repurchase intention in which brand image-congruence plays a dominant role as the value of beta is greater i.e. $(\beta=0.153)$, whereas the value of beta of brand trust is $(\beta=0.062)$. Only brand experience has an insignificant impact on brand repurchase intention. The results confirm that a brand image compatible with customer's self-image is a good vehicle for enhancing their self-image which ultimately results in the repurchase of the apparel brand. In addition, trust plays a role in influencing the consumer to shop online again. These results are similar to the results by Chen-Yu et al. (2016), who found larger impact of trust on online repurchase intention followed by brand image-congruence.

\subsection{Recommendations}

Based on the results and findings, the study recommends to marketing managers and online apparel companies to formulate appropriate marketing strategy and plan to indulge customers into better brand experience and to develop better brand image as it helps them to create a better association with the consumer and also to strengthen consumer's trust. In accordance with the significant results of brand experience and brand image-congruence on brand affect, marketers should research self-image of target customers to create a brand image. Product development department of the apparel industry should also have the brand image-congruence in mind when developing the apparel as it will help brands to create an emotional and favourable connection with the brand. Brand image-congruence should be communicated appropriately by the marketers preferably through lifestyle description and timely in order to gain beneficial outcomes as marketing strategy plays a significant role. Therefore, companies should pay appropriate attention to the development and sustainability of the brand image. Website design department should also consider brand-image congruence element in developing promotional messages.

In accordance with the significant results of brand experience, brand imagecongruence and brand affect on brand trust, companies should develop a website that provides quick feedback i.e. customer service as this will strengthen consumer's confidence in the online apparel brand. Better website structure that provides quick feedback, better design of the branded apparel in consideration of consumer's self-image, will eventually motivate the consumer to repurchase the brand online.

\subsection{Limitations and future recommendations}

This study has certain limitations such as it has only included the data of Karachi, Pakistan. Diversified and larger sample can provide more generalized results. Therefore, it is suggested for future researches to collect data from other 
cities in Pakistan in order to get better insights. Cross-cultural study would lead to important insights since cultural context has proved to be important in previous researches on intentions. For example, individuals from countries that are more collectivistic seem to experience stronger pressure from peers and are more willing to comply with their opinions (Triandis et al., 1988). On the other hand, individuals born and raised in predominantly individualistic countries may have stronger attitudes toward certain behaviours and may pay less attention to what other people think or do. Further, demographic and socio-psychographic variables should also be included in the study to estimate and further deepen the knowledge of associations of variables and their importance with regard to repurchase intention in the online apparel industry. Furthermore, age and educational background can have a mediating or moderating

\section{References}

1. Aggarwal, C. C. (2013). Outlier analysis. New York: Springer.

2. Alba, J. W., \& Hasher, L. (1983). Is memory schematic?. Psychological Bulletin, 93(2), 203-231.

3. Bagozzi, R. P., \& Yi, Y. (1988). On the evaluation of structural equation model. Journal of Academy of Marketing Science, 16 (1), 74-94.

4. Bartless, F. C. (1932). Remembering. Cambridge: Cambridge University Press.

5. Batra, R., Ahuvia, A., \& Bagozzi, R. P. (2012). Brand love. Journal of Marketing, 76(2), 1-16.

6. Bhatnagar, A., Misra, S., \& Rao, H. (2000). On risk, convenience, and internet shopping behavior. Communications of the ACM, 43, 98-105. influence on the relationship between i.e. brand trust and repurchase intention. Young people may be under a stronger influence of their peers, and may therefore modify their behaviour accordingly. In addition, young people are more used to the internet surroundings which can influence the perceived risk.

Finally, future research could be directed towards different levels of specificity, i.e. specific type of clothes (sports clothes, work clothes, designer fashion, etc.) or specific needs, i.e. unique sizes and mass customization (desire for uniqueness) as well as towards the multi-channel perspective (i.e. browsing online and purchasing offline). In addition, other types of brand experience such as website attributes, perceived quality can be taken under consideration to understand the repurchase intention.

7. Bruner, G. C. (2012). Marketing scales handbook: A compilation of multi-item measures for consumer behavior \& advertising. Fort Worth, TX: GCBII Publications

8. Byrne, B. M. (2013). Structural equation modeling with amos: Basic concepts, applications, and programming. New York, London: Routledge.

9. Chaudhuri, A., \& Holbrook, M. B. (2001). The chain of effects from brand trust and brand affect to brand performance: the role of brand loyalty. Journal of Marketing, 65(2), 81-93.

10. Chen-Yu, J., Cho, S., \& Kincade, D. (2016). Brand perception and brand repurchase intent in online apparel shopping: An examination of brand experience, image congruence, brand affect, and brand trust. Journal of Global Fashion Marketing, 7(1), 30-44.

11. Christodoulides, G., De Chernatony, 
L., Furrer, O., Shiu, E., \& Abimbola, T. (2006). Conceptualizing and measuring the equity of online brands. Journal of Marketing Management, 22, 799-825.

12. Coulter, K. S., \& Coulter, R. A. (2002). Determinants of trust in a service provider: The moderating role of length of relationship. Journal of Service Marketing, 16, 35-50.

13. Das, G. (2015). Linkages between self-congruity, brand familiarity, perceived quality and purchase intention. Journal of Global Fashion Marketing, 6, 180-193.

14. Demo, G., Neiva, E. R., Nunes, I., \& Rozzett, K. (2012). Human Resources Management Policies and Practices Scale (HRMPPS): Exploratory and Confirmatory Factor Analysis. BAR, Rio de Janeiro, 9(4), 395-420.

15. Duryee, T. (2012). The hottest trend in e-commerce? Clothes. Retrieved from http://allthingsd.com/20120405/the-hottest-fashion-in-e-commerce-clothes/

16. Enright, A. (2013). US e-commerce sales could top $\$ 413$ billion in 2017. Retrieved from https://www.internetretailer.com/2013/04/25/us-e-commercesales-could-top-434-billion-2017

17. Hair, J. F., Anderson, R. E., Babin, B. J., \& Black, W. C. (2010). Multivariate data analysis: A global perspective (Vol. 7). Upper Saddle River, NJ: Pearson.

18. Hair, J. F., Black, W. C., Babin, B. J., Anderson, R. E., \& Tatham, R. L. (2006). Multivariate data analysis (6th ed.). Upper Saddle River, NJ: PearsonPrentice Hall.

19. Han, H., \& Hyun, S. S. (2013). Image congruence and relationship quality in predicting switching intention. Journal of Hospitality \& Tourism Research, 37, 303-329.

20. Han, J. (2006). The impact of selfconcept/product-image self-congruence and functional selfcongruence on brand preference. Unpublished doctoral dissertation. Florida State University,Tallahassee, FL

21. Hongyoun Hahn, K., \& Kim, J. (2009). The effect of offline brand trust and perceived internet confidence on online shopping intention in the integrated multi-channel context. International Journal of Retail \& Distribution Management, 37(2), 126-141.

22. Iglesias, O., Singh, J. J., \& BatistaFoguet, J. M. (2011). The role of brand experience and affective commitment in determining brand loyalty. Journal of Brand Management, 18(8), 570-582.

23. Jang, H. (2007). A comparative study on the structural interactions among customer satisfaction, trust, loyalty based on types of internet shopping mall. Journal of Global Academy of Marketing Science, 17, 23-49.

24. Jao, J. (2014). Why customer retention is king: The evolution of retention marketing. Retrieved from http://www.forbes. com/sites/jerryjao/2014/11/19/why-customer-retention-is-king-the-evolutionofretention-marketing-part-1/2/

25. Jones, C., \& Kim, S. (2010). Influences of retail brand trust, off-line patronage, clothing involvement and website quality on online apparel shopping intention. International Journal of Consumer Studies, 34, 627-637.

26. Jordan, J. (2013). How to compete with Amazon. Retrieved from http://fortune.com/2013/10/24/ how-to-compete-with-amazon/

27. Keller, K. L. (2003). Brand synthesis: The multi-dimensionalities of brand knowledge. Journal of Consumer Research, 29, 595-600.

28. Kim, H. (2012). The dimensionality of fashion-brand experience. Journal of Fashion Marketing and Management, 16, 418-441. 
29. Kim, H.-N., \& Na, K.-S. (2015). Understanding Repurchase Intention in Online Fashion Shopping Mall. Indian Journal of Science and Technology, 8(S7), 554-562.

30. Kim, M., \& Ock, J. (2008). A study on the relationship between online community characteristics and loyalty: Focused on mediating roles of selfcongruency, consumer experience, and consumer to consumer interactivity. Journal of Global Academy of Marketing Science, 18, 159-196.

31. Kline, R. B. (2011). Principles and Practice of Structural Equation Modeling ( $3 r d$ ed.). London: The Guilford Press.

32. Kressmann, F., Sirgy, M. J., Herrmann, A., Huber, F., Huber, S., \& Lee, D. J. (2006). Direct and indirect effects of self-image congruence on brand loyalty. Journal of Business Research, 59, 955-964.

33. Lau, G. T., \& Lee, S. H. (1999). Consumers' trust in a brand and the link to brand loyalty. Journal of Marketing Focused Management, 4, 341-370.

34. Lee, E. M., Park, S., \& Pae, J. H. (2011). The Effect of the perceived corporate fit on loyalty: The mediating roles of the corporate social responsibility perception. Journal of Global Academy of Marketing Science, 21, 32-44.

35. Lin, M., \& Lee, B. C. (2012). The influence of website environment on brand loyalty. International Journal of Electronic Business Management, 10, 308-321.

36. Loureiro, S. M. C., Ruediger, K. H., \& Demetris, V. (2012). Brand emotional connection and loyalty. Journal of Brand Management, 20, 13-27.

37. Maxham III, J. G., \& Netemeyer, R. G. (2003). Firms reap what they sow: the effects of shared values and perceived organizational justice on customers' evaluations of complaint handling. Journal of Marketing, 67(1), 46-62.

38. Meijinders, A., Midden, C., Olofsson, A., Ohman, S., Matthes, J., Bondarenko, O., \& Rusanen, M. (2009). The role of similarity cues in the development of trust in sources of information about GM food. Risk Analysis, 29, 1116-1128.

39. Moon, J. (2007). Corporate image effects on consumers' evaluation of brand trust and brand affect. Journal of Global Academy of Marketing Science, 17, 21-37.

40. Morgan, R. M., \& Hunt, S. D. (1994). The commitment-trust theory of relationship marketing. Journal of Marketing, 58, 20-38.

41. Morwitz, V. G., Steckel, J. H., \& Gupta, A. (2007). When do purchase intentions predict sales? International Journal of Forecasting, 23(3), 347-364.

42. PakistanToday (2018, Sep 20). Pakistan's e-commerce market witnesses significant growth. Retreived from https://profit.pakistantoday.com. pk/2018/09/20/pakistans-e-commercemarket-witnesses-significant-growth/

43. Park, J., \& Stoel, L. (2005). Effect of brand familiarity, experience and information on online apparel purchase. International Journal of Retail \& Distribution Management, 33, 148-160.

44. Park, M., \& Lennon, S. J. (2009). Brand name and promotion in online shopping contexts. Journal of Fashion Marketing and Management, 13, 149-160.

45. Peter, J. P., \& Olson, J. C. (2010). Consumer behavior \& marketing strategy. New York, NY: McGraw- Hill. 
46. Rhee, J., \& Johnson, K. (2012). Investigating relationships between adolescents' liking for an apparel brand and brand self-congruency. Young Consumers: Insight and Ideas for Responsible Marketers, 13, 74-85.

47. Rocereto, J. F. (2007). Consumer selfconcept and retail store loyalty: The effects of consumer self-concept on consumer attitude and shopping behavior among brand- specific and multibrand retail stores. Unpublished doctoral dissertation, Drexel University, Philadelphia.

48. Sharifi, S., \& Esfidani, M. (2014). The impacts of relationship marketing on cognitive dissonance, satisfaction, and loyalty. International Journal of Retail \& Distribution Management, 42, 553-575.

49. Shaw, C. (2013). 15 statistics that should change the business world - but haven't. Retrieved from: https://www. linkedin.com/pulse/20130604134550284615-15-statistics-that-shouldchange-thebusiness-world-but-haven-t.

50. Shim, S. I. (2012). Enhancing brand loyalty through brand experience: Application of online flow theory. Unpublished doctoral dissertation, Auburn University, Auburn.

51. Sirgy, M. J. (1985). Using self-congruity and ideal congruity to predict purchase motivation. Journal of business Research, 13(3), 195-206.

52. Smith, M., \& Brynjolfsson, E. (2001). Consumer decision-making at an internet shopbot: Brand still matters. Journal of Industrial Economics, 49, 541-558.

53. Spector, A. J. (1961). Basic dimensions of the corporate image. The Journal of Marketing, 47-51.

54. Statista (2018). Retail e-commerce sales worldwide from 2014 to 2021 (in billion U.S. dollars). Retrieved from https://www.statista.com/ statistics/379046/worldwide-retail-ecommerce-sales/. Accessed on 30th November 2018

55. Tax, S. S., Brown, S. W., \& Chandrashekaran, M. (1998). Customer evaluations of service complaint experiences: implications for relationship marketing. The Journal of Marketing, 60-76.

56. Temkin, B., Chu, W., \& Geller, S. (2009). Customer experience correlates to loyalty. Forrester. 17th February. Retrieved from https://experiencematters.wordpress.com/2009/02/18/customer-experience-correlates-to-loyalty.

57. Triandis, H. C., Bontempo, R., Villareal, M. J., Asai, M., \& Lucca, N. (1988). Individualism and collectivism: Cross-cultural perspectives on selfingroup relationships. Journal of personality and Social Psychology, 54(2), 323.

58. Walter, N., Cleff, T., \& Chu, G. (2013). Brand experience's influence on customer satisfaction and loyalty. International Journal of Management Research and Business Strategy, 2, 130-144.

59. Weisberg, J., Te'eni, D., \& Arman, L. (2011). Past purchase and intention to purchase in e-commerce. Internet Research, 21, 82-96.

60. Williams, J. (2014). BIA/Kelsey and manta joWint report: SMBs shift priority to customer retention. Retrieved from: http://blog.biakelsey.com/index. php/2014/04/03/biakelsey-and-mantajointreport-smbs-shift-priority-to-customer-retention/.

61. Yoon, D., \& Youn, S. (2016). Brand experience on the website: its mediating role between perceived interactivity and relationship quality. Journal of Interactive Advertising, 16(1), 1-15. 


\section{UTJECAJ ČIMBENIKA PERCEPCIJE TRŽIŠNE MARKE NA POTROŠAČKU NAMJERU PONOVNE KUPOVINE: ISTRAŽIVANJE ON-LINE KUPOVINE ODJEĆE}

\section{Sažetak}

Cilj ovog rada je utvrditi utjecaj percepcije tržišne marke na potrošačku namjeru nove kupovine u slučaju on-line kupovine odjeće u Pakistanu. Rad se zasniva na pristupu, koji je $u$ većoj mjeri holistički, u odnosu na prethodne studije, pri čemu se u obzir uzimaju višestruke teorije i koncepti percepcije tržišne marke, kako bi se obuhvatili kompleksni utjecaji i objasnila namjera ponovne kupovine kao zavisna varijabla. Teorijski okvir rada razvijen je na temelju teorija mentalnih nacrta, podudarnosti imidža, kao i teorije posvećenosti te povjerenja. Također su korišteni i rezultati prethodnih empirijskih istraživanja. Ukupno je prikupljeno 396 odgovora on-line potrošača iz područja Karachija, u Pakistanu, korištenjem prigodnog, neprobabilističkog uzorka. Kao metode obrade podataka, korišteni su eksploratorna faktorska analiza (EFA) te metoda strukturnih jednadžbi (SEM), korištenjem softverskih alata SPSS 22 i AMOS 22. Rezultati istraživanja pokazuju značajan pozitivan utjecaj svih predloženih konstrukata na namjeru ponovne kupovine, osim za prethodno iskustvo s tržišnom markom.

Ključne riječi: namjera ponovne kupovine, iskustvo s tržišnom markom, povjerenje u tržišnu marku, emotivno djelovanje tržišne marke, imidž tržišne marke, on-line kupovina odjeće, Pakistan 